\title{
Сортоизучение бамии в условиях защищенного грунта III световой зоны
}

\section{А.В. Константинович, В.И. Терехова, М.Е. Дыйканова}

Представлены результаты сортоиспытания бамии в условиях грунтовых весенних пленочных теплиц. На основе полученных данных по урожайности культуры бамии в условиях пленочных теплиц выявлен наиболее урожайный сорт Дамские пальчики, превышение урожайности по сравнению с другими сортами составило 0,3-1,3 кг/м² что обусловлено большим количеством плодов на одном растении и средней массой.

Ключевые слова: бамия, урожайность, пленочные теплицы, товарные качества продукции.

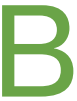
последние годы возрос интерес к расширению сортимента овощных культур сельхозпроизводителями за счет внедрения в производство малораспространенных и нетрадиционных культур для России, обладающих ценными и полезными свойствами.

Родина бамии (Abelmoschus esculentus L.), другие названия: окра, гомбо, дамские пальчики, гибискус съедобный,- тропическая Африка. Основные посевные площади сосредоточены в ряде стран Южной Европы, Америке, Африке и Азии. Лидеры среди стран-производителей - Индия (6,3 млн т), Нигерия $(1,1$ млн т), Судан (0,2 млн т) [1]. На территории России бамию выращивают на небольших площадях в Краснодарском крае, Республике Северная Осетия-Алания.

Бамия - однолетняя культура из семейства мальвовых (Malvaceae). В пазухах листьев формируются плоды: четырехгранная или восьмигранная многосемянная коробочка. В пищу употребляют только молодые (3-6 дней) завязи зеленой окраски [2]. Срезают их через каждые 2-3 суток, не допуская перезревания, т.к. перезрелые плоды становятся грубыми, во- локнистыми (рис. 1, 2). Плоды бамии - диетический продукт, богатый белком, аскорбиновой кислотой, каротином и витаминами группы В. По вкусу плоды напоминают баклажан и спаржу, что определяет их широкое применение в кулинарии. Семена бамии содержат 24-26\% сырого протеина, жирного масла - 32-42\%, сырой клетчатки $17-19 \%$, аскорбиновой кислоты до 45 мг\%, что позволяет получать масло, имеющее пищевое и техническое значение, а также использовать шрот или жмых в производстве белковых обогатителей [3].

Цель исследований: выявление наиболее урожайных сортов бамии при выращивании в весенних пленочных теплицах III световой зоны.

Исследования проводили в 20182019 годах в весенней пленочной грунтовой теплице на солнеч«Овощная опытная станция имени В.И. Эдельштейна».

Объект исследований: сорта бамии: Влада, Бомбей, Дамские пальчики [4].

Сорт Дамские пальчики - среднеспелый, высота растения 150180 см. Урожайность завязей составляет 1,4-1,6 кг/м². ном обогреве на территории УНПЦ
Продуктивность, параметры плода и урожайность бамии в весенних пленочных теплицах (среднее за 2018-2019 годы)

\begin{tabular}{|l|c|c|c|c|c|}
\hline \multicolumn{1}{|c|}{ Сорт } & $\begin{array}{c}\text { Продуктивность, } \\
\text { шт/раст. }\end{array}$ & \multicolumn{3}{|c|}{ Параметры плода } & $\begin{array}{c}\text { Урожайность } \\
\text { длина, см }\end{array}$ \\
\hline $\begin{array}{l}\text { Дамские } \\
\text { пальчики }\end{array}$ & 32 & $8-10$ & 1,7 & 16,3 & 2,4 \\
\hline Бомбей & 29 & $7-9$ & 2,0 & 15,9 & 2,1 \\
\hline $\begin{array}{l}\text { Красный } \\
\text { бархат }\end{array}$ & 18 & $5-6$ & 2,4 & 13,5 & 1,1 \\
\hline
\end{tabular}

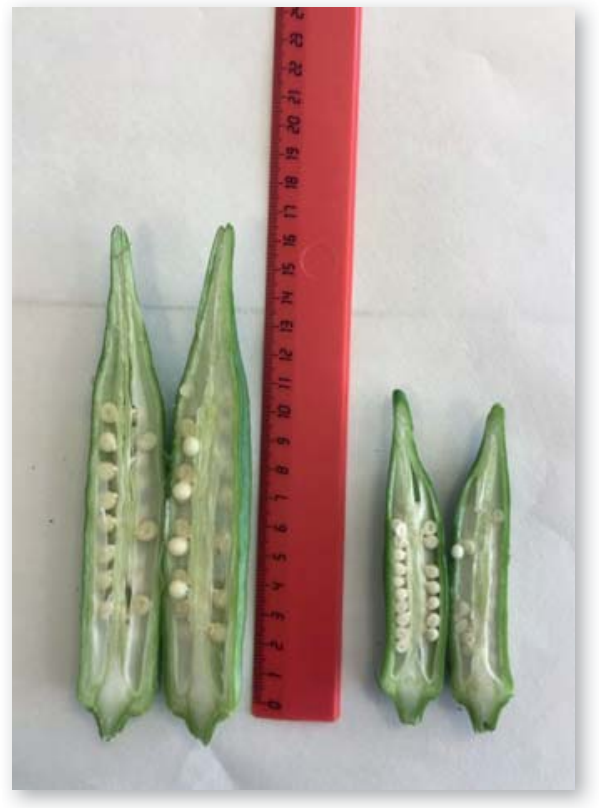

Рис. 1. Нестандартные и стандартные плоды бамии

Сорт Бомбей - среднеспелый, высота растения 110-120 см. Урожайность завязей составляет

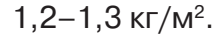

Сорт Красный бархат - среднеспелый, высота растений 100110 см. Урожайность завязей состав-



Посев семян для получения рассады - в третьей декаде марта в кассеты с объемом ячейки $180 \mathrm{~cm}^{3}$, возраст рассады 40 суток. Схема размещения растений при посадке в теплицу 90+50×30 см во второй декаде мая. Варианты размещали в трехкратной повторности по 20 растений в каждой. Площадь опытной делянки составляла $5,5 \mathrm{~m}^{2}$ [3]. Агротехника в опыте: при выращивании использовали черный нетканый мульчирующий материал; формировка растений в один стебель; полив - в среднем раз в 7 дней; собирали продукцию в возрасте 3-6 дневной завязи.

По результатам фенологических наблюдений установлено, что у растений сорта Дамские пальчики и Бомбей цветение начинается на 78 сутки, в отличие от растений 




Pис. 2. Стандартный плод бамии в разрезе

Красный бархат, у которого цветение отмечено на 10 суток позже. Первый сбор провели на 87 сутки после появления всходов (рис. 3), а последующие через каждые 3-4 сутки. Растения сортов Дамские пальчики и Бомбей характеризуются более ранним сроком формирования продукции по сравнению с сортом Красный бархат. Результаты биометрических наблюдений указывают на интенсивный рост растений в первый период вегетации, который состав-

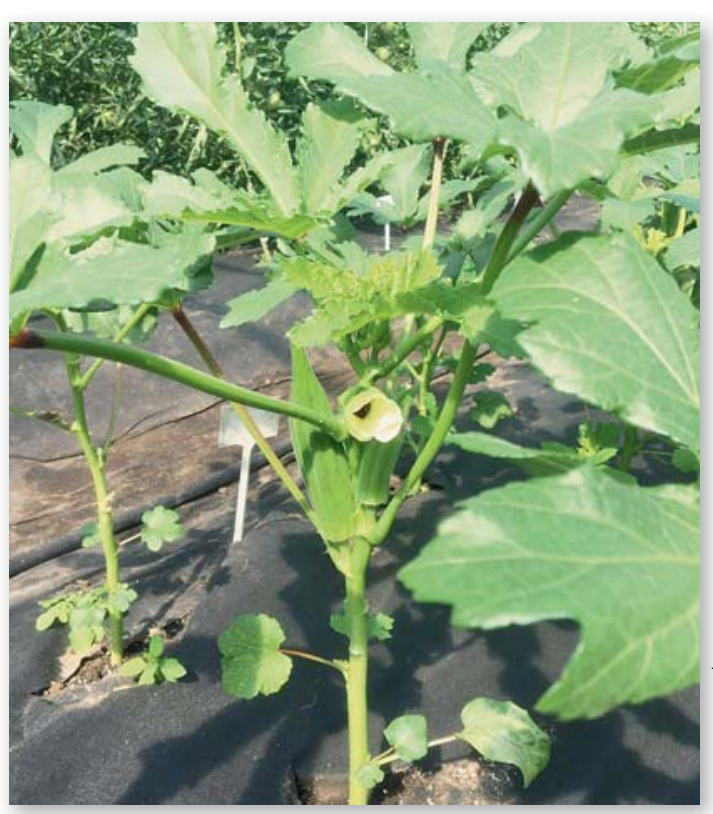

ляет 15-17 см за 10 дней, во время массового плодоношения интенсивность роста снижается до 8-10 см за 10 дней. Среднее количество листьев на одном растении составляет от 18 до 28 в зависимости от сорта. Растения сорта Красный бархат отличаются менее интенсивным ростом и количеством листьев.

На основе полученных данных по урожайности культуры бамии в условиях пленочных теплиц выявлен наиболее урожайный сорт Дамские пальчики, превышение урожайности по сравнению с другими сортами со-

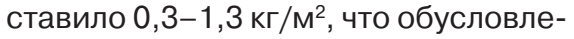
но большим количеством плодов на одном растении и средней массой. Данные по урожайности представлены в таблице.

Результаты исследований позволяют сделать вывод о возможности выращивания бамии в условиях весенних пленочных теплиц III световой зоны при использовании высокоурожайных сортов (рис. 4) и применении мульчирующих материалов, позволяющих обеспечивать необходимую температуру почвы и сохранять достаточное количество влаги, что соответствует биологическим требованиям растений, особенно в период плодообразования.

\section{Библиографический список}

1.Жаров А.Н., Попов В.П., Жарова Л.Л. Оценка производства бамии в мире // Вестник РУдн, серия Агрономия и животноводство. 2009. №3. С. $5-13$

2.Овощи мира. Энциклопедия мировых биологических ресурсов овощных растений. Сост.: М.С. Бунин, А.В. Мешков, В.И. Терехова, А.В. Константинович; под общ. ред. доктора с.-х. наук, проф. М.С. Бунина. М.: ГнУ ЦНСХБ Россельхозакадемии, 2013. 496 с. 3.Хлебников В.Ф., Смурова Н.В., Смурова Н.В. Биологические аспекты семенной продуктивности гибискусса съедобного (бамии) в условиях Приднестровья // Новые и нетрадиционные растения и перспективы их использования. 2017. №512. С. 202-204.

4.Государственный реестр селекционных достижений, допущенных к использованию [Электронный ресурс]. URL: https://reestr.gossort.com/reestr/search. Дата обращения 21.01.2019

5.Литвинов С.С. Методика полевого опыта в овощеводстве. М. Россельхозакадемия, 2011. 648 с.

\section{Об авторах}

Константинович Анастасия Владимировна, канд. с. -

х. наук, доцент, зав. кафед-

рой овощеводства, ФГБОУ ВО

РГАУ-МСХА имени

К.А. Тимирязева.

E-mail: rumexred@gmail.com



Рис. 4. Растения бамии в пленочной теплице

Терехова Вера Ивановна, доцент, канд. с.-х. наук, доцент кафедры овощеводства, ФГБОУ ВО РГАУ-МСХА имени К.А. Тимирязева.

E-mail:vterechova@yandex.ru

Дыйканова Марина Евгеньевна, канд. с.-х. наук, старший преподаватель кафедры овощеводства, ФГБОУ ВО РГАУ-МСХА имени

К.А. Тимирязева.

E-mail:dme3@mail.ru

Study of okra cultivars growing in greenhouses of III light zone

A.V. Konstantinovich, $P h D$, associate

professor, head of vegetable growing chair Russian State Agrarian University - Moscow Timiryazev Agricultural Academy.

E-mail: rumexred@gmail.com

V.I. Terekhova, PhD, associate professor, vegetable growing chair, Russian State Agrarian University - Moscow Timiryazev Agricultural Academy.

E-mail: vterechova@yandex.ru

M.E. Dyikanova, PhD, senior lecturer, head of vegetable growing chair, Russian State Agrarian University - Moscow Timiryazev Agricultural Academy.

E-mail:dme3@mail.ru

Summary. The results of okra variety testing in soil spring film greenhouses are presented. Based on data of yield of okra in conditions of film greenhouses the most productive variety, Damskiye palchiki, the excess yield compared to other varieties was 0.3$1.3 \mathrm{~kg} / \mathrm{m}^{2}$, that due to the large number of fruits per plant and average weight.

Keywords: okra, productivity, film greenhouses, product quality.

Рис. 3. Начало плодоношения бамии 